\title{
PERFORMA REPRODUKSI BABI BALI JANTAN DI PROVINSI BALI SEBAGAI PLASMA NUTFAH ASLI BALI
}

\author{
SUMARDANI, N. L. G., I. W. SUBERATA, N. M. A. RASNA, DAN I. N. ARDIKA \\ Fakultas Peternakan, Universitas Udayana, Denpasar, Bali \\ e-mail: nlg_sumardani@unud.ac.id
}

\begin{abstract}
ABSTRAK
Penelitian ini bertujuan untuk mengetahui performa reproduksi babi bali jantan sebagai salah satu indikator dalam pemilihan bibit babi jantan, serta untuk mengetahui produktivitas babi bali pejantan sebagai plasma nutfah asli Bali. Penelitian dilaksanakan selama 3 bulan mulai bulan Juni sampai Agustus 2016. Penelitian ini menggunakan metode survei secara purposive random sampling dan pendekatan eksploratif serta pemilihan lokasi penelitian berdasarkan waktu dan biaya penelitian. Ekterior calon pejantan ada dua yaitu yang berwarna hitam dan berwarna hitam dengan belang putih pada keempat kakinya. Dimensi tubuh calon pejantan dengan panjang badan riil rata-rata $52 \mathrm{~cm}$, dimensi testis panjang rata-rata 7,37 cm dan lebar 7,62 cm. Dimensi tubuh dan testis, berkaitan erat dengan aktivitas dan produktivitas calon pejantan. Semakin tinggi dimensi tubuh dan testis calon pejantan, akan berpengaruh secara nyata pada performa reproduksi dari pejantan.
\end{abstract}

Kata kunci: babi bali pejantan, performa reproduksi, testis, plasma nutfah.

\section{REPRODUCTION PERFORMANCE OF BALINESE BOAR AS GERMPLASM IN BALI}

\begin{abstract}
ABSTRACK
This study aims to determine the reproduction performance of the balinesse boar as an indicator of seed selection boar, as well as to determine the productivity of the boar as the original germplasm Bali. Research was conducted during three months from June to August 2016. This study used purposive random sampling survey and exploratory approach and research locations based on the time and cost of the study. Exterior bali pig have two colours, black and black with white stripes on four legs. Body dimensions boar with a body length of the average real $52 \mathrm{~cm}$, testicular dimension average length of $7.37 \mathrm{~cm}$ and wide of $7.62 \mathrm{~cm}$. Dimensions body and testis, is closely related to the activity and productivity of boar. The higher the body dimensions and testis of boar, will affect significantly the reproduction performance of the boar.
\end{abstract}

Keywords: balinese boar, reproduction performance, testis, germplasm.

\section{PENDAHULUAN}

Babi merupakan hewan yang telah dipelihara dan dikembangkan sejak dahulu untuk tujuan memenuhi kebutuhan akan daging bagi umat manusia. Babi merupakan salah satu komoditas ternak penghasil dagingyang memiliki potensi besar untuk dikembangkan karena memiliki sifat-sifat dan kemampuan yang menguntungkan antara lain: laju petumbuhan yang cepat, jumlah anak per kelahiran (litter size) yang tinggi, efisien ransum yang baik (70-80\%), dan persentase karkas yang tinggi (65-80\%) (Ardana dan Putra, 2008). Selain itu, babi mampu memanfaatkan sisa-sisa makanan atau limbah pertanian menjadi daging yang bermutu tinggi (Budaarsa et al., 2016). Karakteristik reproduksinya unik bila dibandingkan dengan ternak sapi, domba dan kuda, karena babi merupakan hewan yang memiliki sifat prolifik yaitu jumlah perkelahiran yang tinggi (10-14 ekor/kelahiran), serta jarak antara satu kelahirann dengan kelahiran berikutnya pendek (Sihombing, 2006; Sudiastra dan Budaarsa, 2015).

Dalam usaha pengembangan dan peningkatan produktivitas babi bali, performa reproduksi memegang peranan penting dikaitkan dengan usaha peningkatan produksi ternak babi bali tersebut. Performa reproduksi babi bali tidak saja dititikberatkan pada ternak babi betina, tetapi juga pada ternak babi jantan, karena berhasil tidaknya suatu perkembangan populasi ataupun generasi baru, tergantung dari ada tidaknya perkawinan antara jantan dan betina. Mengetahui per- 
forma reproduksi ternak babi bali akan memudahkan usaha-usaha peningkatan populasi ternak babi bali, dan merupakan bahan pertimbangan dalam menentukan kebijakan yang berhubungan dengan usaha peningkatan produksi ternak babi bali sebagai salah satu plasma nutfah asli Bali.

Performa reproduksi babi bali jantan yang meliputi ukuran testis dan kualitas semen, berkaitan erat dengan aktivitas dan kemampuan pejantan untuk mengawini sejumlah betina, memproduksi semen, dan tingginya fertilitas. Produksi optimum semen pada masingmasing bangsa berbeda menurut potensi genetiknya. Perbaikan kondisi bobot badan mampu meningkatkan volume semen dan besarnya ukuran testis, sedangkan kualitas semen sangat ditentukan oleh ukuran testis (Sihombing, 2006). Pemilihan bibit pejantan yang baik dan memenuhi persyaratan, akan mempengaruhi keberhasilan suatu usaha peternakan. Testis babi sangat besar tetapi relatif lebih lunak, dan terletak horizontal di dalam skrotom (Girisonta, 1981). Testis babi berbentuk lonjong, dengan ukuran panjang 10-15 $\mathrm{cm}$ diameter 5-9 cm (Toelihere, 1985; Feradis, 2010). Besar skrotom berkorelasi positif terhadap besarnya testis. Menurut Boyles (1991) bahwa besar dan lingkar skrotom sapi berkorelasi positif dengan sperma yang dihasilkan oleh pejantan meliputi volume dan motilitas sperma serta konsentrasi seprmatozoa. Melalui pengukuran skrotom dapat diketahui kemampuan produksi sperma seekor pejantan dan dapat dimanfaatkan sebagai salah satu kriteria seleksi seekor pejantan (Ningrum et al., 2008). Selain itu, ukuran skrotom juga berhubungan dengan umur dan berat tubuh dari berbagai bangsa babi. Perkembangan skrotom berjalan sesuai dengan pertumbuhan dan perkembangan tubuh secara keseluruhan. Semakin besar skrotom semakin banyak tubuli seminiferi dan makin banyak pula sperma yang dihasilkan (Hafez, 1993).

Berdasarkan hal tersebut diatas, penelitian ini dilakukan untuk mengetahui performa reproduksi babi bali jantan dalam kaitannya dengan pemilihan bibit pejantan yang baik dan memenuhi persyaratan, serta pengadaan bibit babi bali dan usaha pelestarian plasma nutfah asli Bali, dan juga usaha-usaha peningkatan populasi ternak babi bali. Selain itu juga, merupakan bahan pertimbangan dalam menentukan kebijakan yang berhubungan dengan usaha peningkatan produksi ternak babi bali sebagai salah satu plasma nutfah asli Bali.

\section{MATERI DAN METODE}

Penelitian dilaksanakan selama 3 bulan mulai bulan Juni sampai Agustus 2016. Penelitian ini menggunakan metode survei secara purposive random sampling dan pendekatan eksploratif serta pemilihan lokasi penelitian berdasarkan waktu penelitian. Pengumpulan data dilakukan dengan teknik wawancara menggunakan kuisioner (daftar pertanyaan) dan informasi tambahan yang dibutuhkan diperoleh melalui observasi langsung di lapangan ataupun melalui wawancara dengan orang/ organisasi yang berperan seperti misalnya kelompok peternak, tenaga inseminator dan instansi terkait. Pemilihan calon pejantan (babi bali jantan). Babi bali jantan yang digunakan sebanyak 4 (empat) ekor dengan status fisiologis sehat. Persiapan alat-alat pengukuran babi bali, meliputi penimbangan dan pengukuran dimensi tubuh babi bali jantan, serta pengukuran organ reproduksi babi bali jantan. Variabel yang diamati meliputi: bobot badan, dimensi tubuh, dimensi testis, dan korelasinya.

\section{HASIL DAN PEMBAHASAN}

\section{Pemeliharaan Ternak Babi Bali}

Sistem pemeliharaan ternak babi bali di wilayah pengambilan sampel secara keseluruhan adalah dengan sistem tradisional yaitu mengikat ternak babi dengan tali, di bawah pepohonan (Gambar 1). Panjang tali pengikat 1,5-2 meter. Dalam kondisi tersebut, ternak babi akan selalu ternaungi pada waktu siang hari, dan akan selalu kehujanan pada musim hujan. Pemeliharaan ternak babi di wilayah ini sangat jarang membuat kandang beratap, ataupun kandang permanen.

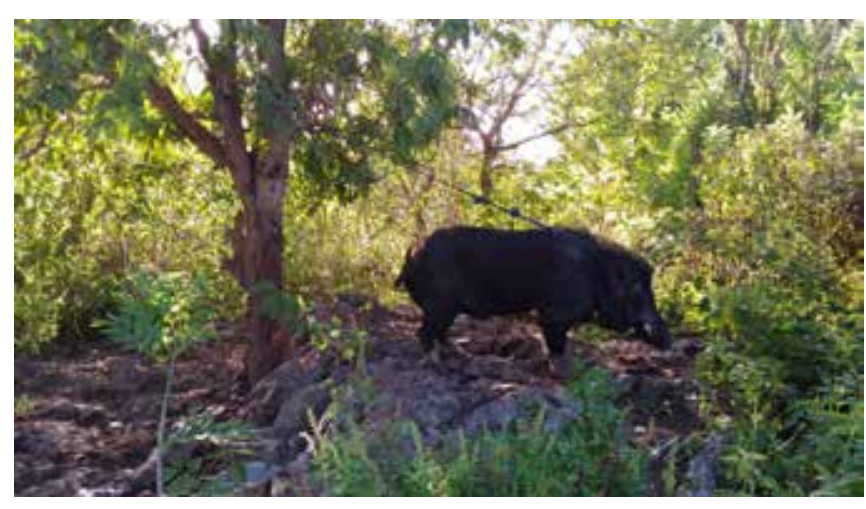

Gambar 1. Ternak babi jantan yang dipelihara secara tradisional di bawah pohon, dengan mengikat pada bagian lehernya menggunakan tali

Di wilayah Nusa Penida, pemeliharaan pejantan ada yang masih diikat di bawah pohon, ada juga yang sudah dikandangkan. Kandang yang digunakan terbuat dari beberapa buah batako yang ditumpuk sedemikian rupa, dan ada juga yang terbuat dari kayu atau bambu, dan dikelilingi oleh kawat berduri. Alasannya agar babi pejantan tersebut tidak meloncat keluar kandang, mengingat tingkah laku pejantan dewasa cukup beringas 
dan galak. Tempat makan yang digunakan sangatlah sederhana, terbuat dari ban bekas yang dibelah, pancipanci bekas, dan juga ember-ember yang sudah tidak digunakan oleh penduduk setempat. Namun demikian, ada beberapa peternak yang sudah membuat tempat pakan secara permanen dari cetakan semen, khususnya pada peternak yang sudah memelihara ternak babi dalam kandang semi permanen (Gambar 2).

Pemeliharaan ternak babi secara tradisional dan juga semi permanen, memberikan kesan kumuh dan jorok. Hal ini karena lantai kandang tidak dipelester sehinga tanah disekitarnya akan selalu lembab dan becek, akibat dari limbah kotoran ternak bercampur dengan urine yang dihasilkan, serta sisa-sisa pakan ternak yang tumpah, sehingga ternak babi akan terlihat selalu kotor. Hal ini mengakibatkan ternak babi bali sangat rawan terinfeksi cacing dan parasit lainnya. Namun hal ini dapat dimaklumi, mengingat kenyataan bahwa tingkah laku ternak babi yang masih liar, lebih suka berkubang di lumpur, untuk mengurangi cekaman panas.

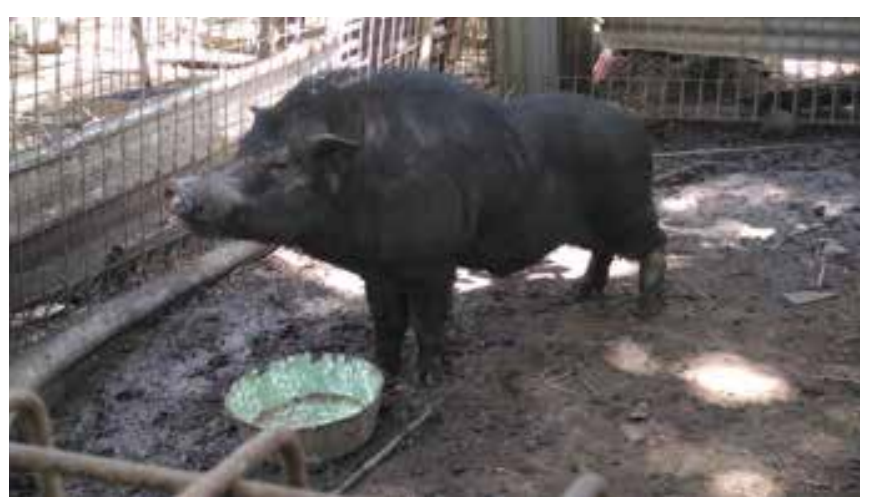

Gambar 2. Ternak babi jantan yang dipelihara secara tradisional di dalam kandang semi permanen

Babi bali yang dipelihara di wilayah Nusa Penida masih secara tradisional dengan pemberian pakan tergantung apa yang ada di sekitarnya, antara lain umbiumbian, batang pisang (gedebong pisang), bungkil kelapa, dan limbah dapur. Pemberian pakan tersebut dimasak terlebih dahulu sebelum diberikan ke ternak babi yang di pelihara.

\section{Tampilan Eksteriur Babi Bali Pejantan}

Ciri khas dari babi bali adalah bentuk tubuh yang melengkung ke bawah (lordosis), baik pada jantan maupun betina. Pada babi pejantan (kaung), lordosis tidak terlalu dalam, sebagaimana lordosis pada babi induk (bangkung). Masyarakat di wilayah Nusa Penida memberikan sebutan "raden" pada babi bali yang digunakan sebagai pejantan.

Warna babi bali jantan di wilayah Nusa Penida didominasi warna hitam secara menyeluruh (Gambar 3), disertai belang putih pada bagian kaki, seolah-olah memakai kaos kaki putih. Bulu pada bagian leher atas agak kasar, berdiri, dan sangat panjang, antara 6-10 $\mathrm{cm}$, dan merata dari depan ke belakang. Bulu punggung ini akan berdiri tegak apabila babi pejantan ini merasa terusik dan terganggu (Gambar 3). Babi jantan dan induk mempunyai bulu lebih panjang dibandingkan babi dara, dan bulu terpanjang berada tepet di belakang kepala.

Ukuran tubuh babi bali secara umum lebih kecil jika dibandingkan dengan ukuran tubuh babi ras. Hasil penelitian Sudiastra dan Budaarsa (2015) menyebutkan bahwa tinggi babi bali sekitar $49 \mathrm{~cm}$, dengan lingkar dada antara 90-136 cm, lingkar perut antara 95-136 cm dan lingkar pinggang 80-115 cm, panjang kepala 20-25 $\mathrm{cm}$, panjang daun telinga rata-rata $10 \mathrm{~cm}$, dan panjang ekor $20-25 \mathrm{~cm}$.

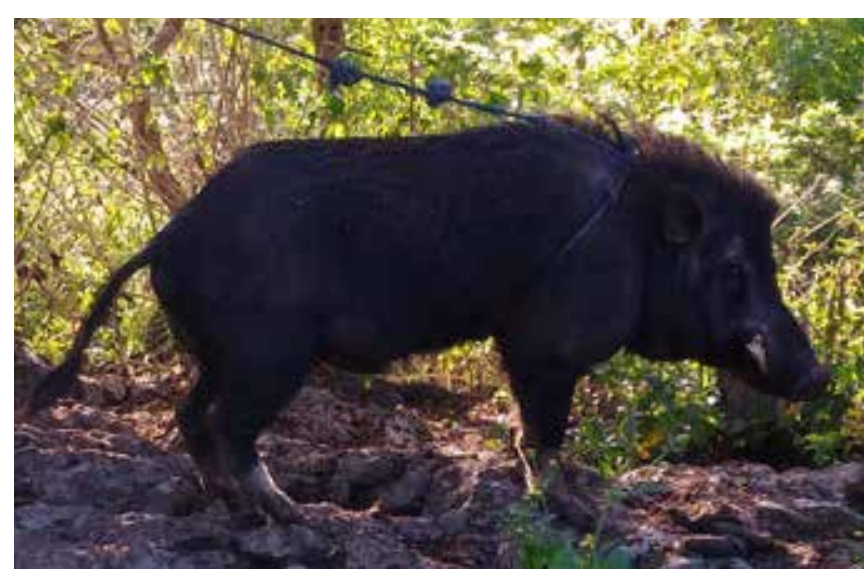

Gambar 3. Babi bali pejantan di Nusa Penida

\section{Bibit babi pejantan}

Performa reproduksi babi bali jantan yang meliputi ukuran testis dan kualitas semen, berkaitan erat dengan aktivitas dan kemampuan pejantan untuk mengawini sejumlah betina, memproduksi semen, dan tingginya fertilitas. Produksi optimum semen pada masingmasing bangsa berbeda menurut potensi genetiknya. Perbaikan kondisi bobot badan mampu meningkatkan volume semen dan besarnya ukuran testis, sedangkan kualitas semen sangat ditentukan oleh ukuran testis (Sihombing, 2006). Pemilihan bibit pejantan yang baik dan memenuhi persyaratan, akan mempengaruhi keberhasilan suatu usaha peternakan.

Sistem perkawinan ternak babi bali di wilayah Nusa Penida, secara dominan masih menggunakan sistem kawin alami, yaitu betina yang sedang berahi akan dikawinkan dengan pejantan yang ada disekitar wilayah tersebut. Biaya atau ongkos pejantan dibayar dengan satu ekor anak babi. Pemilik pejantan akan dibayar 
dengan satu ekor anak babi lepas sapih (umur 2-3 bulan) dari hasil perkawinan ternak tersebut (Gambar 4).

Ternak babi berdasarkan fase pertumbuhannya dapat dibagi menjadi tiga yaitu : Starter, fase hidup anak babi semenjak menyusui sampai umur 8 atau sampai 11 minggu, Grower, fase hidup anak babi sesudah fase stater sampai dengan umur 10 atau sampai 24 minggu, Finisher, anak babi yang menjelang dewasa (Girisonta, 1981).

Pertumbuhan menurut Williams (1982) adalah perubahan bentuk dan ukuran seekor ternak yang dapat dinyatakan dengan panjang, volume, ataupun massa. Sedangkan menurut Swatland (1984) dan Aberle (2001), pertumbuhan dapat dinilai sebagai peningkatan tinggi, panjang, ukuran lingkar dan bobot yang terjadi pada seekor ternak muda yang diberi pakan, minum dan mendapat tempat yang layak.

Kay dan Housseman (1987) menyatakan bahwa hormon androgen pada hewan jantan dapat meransang pertumbuhan sehingga hewan jantan lebih besar dibandingkan dengan betina. Tillman et al. (1991) menyatakan bahwa pertumbuhan mempunyai tahap cepat dan lambat. Tahap cepat terjadi sebelum dewasa kelamin dan tahap lambat pada fase awal dan saat kedewasaan tubuh telah tercapai. Pertumbuhan dimensi tubuh hewan pada saat tumbuh cepat biasanya mengikuti fungsi eksponensial dengan laju pertumbuhan yang berbeda-beda antara dimensi tubuh yang satu dengan dimensi tubuh yang lainnya. Perbedaan kecepatan pertumbuhan ini disebabkan karena perbedaan fisiologis dan tuntutan fungsional yang berbeda, serta komponen penyusunnya.

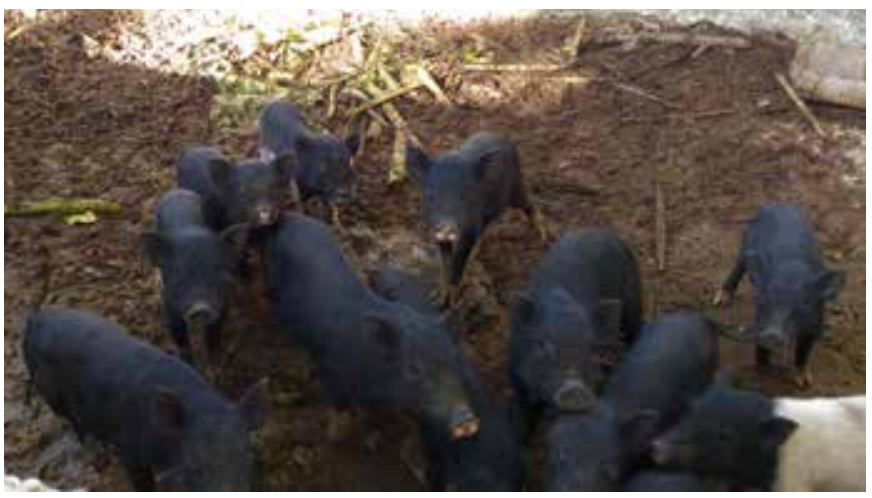

Gambar 4. Babi bali bibit di Nusa Penida

Menurut Sampurna et al. (2015), dimensi tubuh yang diukur meliputi: panjang kepala, panjang punggung, panjang ekor, panjang leher, lingkar leher, lingkar dada, leher perut, lingkar pinggang, panjang kaki depan bagian atas dan bagian bawah, panjang kaki belakang bagian atas dan bagian bawah, lebar kepala, lebar leher, lebar dada, lebar pinggul dan lebar pantat.

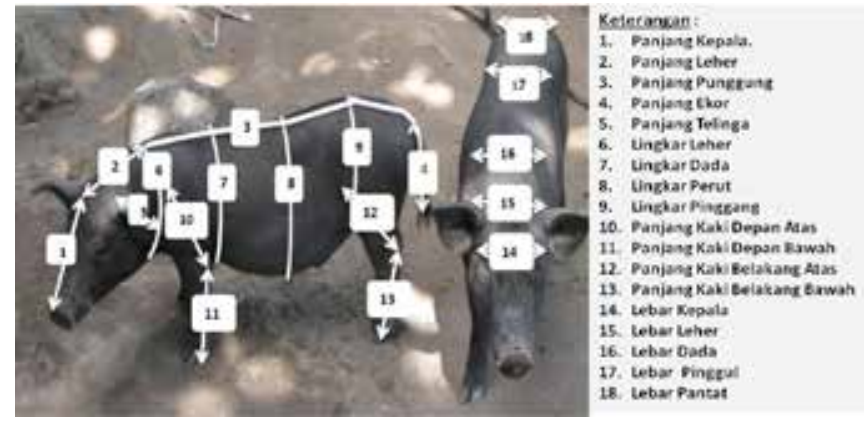

Gambar 5. Cara pengukuran dimensi tubuh babi bali.

1. Panjang kepala diukur dari ujung hidung (planum nasolabiale) sampai perbatasan Intercornuale dorsale garis median

2. Panjang leher diukur dari perbatasan intercornuale sampai pada garis tegak yang ditarik dari tuberositas lateralis dari humerus (sendi bahu/articulatio scapulo humeri).

3. Panjang punggung

4. Panjang ekor adalah jarak antara pangkal ekor (vertebrae coccygeaeperlama) dengan ujung tulang ekor terakhir (vertebree coccygeae)

5. Panjang telinga adalah jarak antara pangkal telingan dengan ujung telinga

6. Lingkar leher diukur dengan cara melingkari leher di depan sendi bahu (articulatio scapulo humeralis) tegak lurus terhadap bidang median tubuh.

7. Lingkar dada diukur dengan jalan melingkari dada dibelakang sendi siku, tegak lurus vertikal bidang median tubuh.

8. Lingkar perut diukur dengan jalan melingkari perut, tegak lurus vertikal bidang median tubuh

9. Lingkar pinggang diukur dengan jalan melingkari pada abdomen di depan tuber coxae pelvis tegak lurus terhadap bidang median tubuh

10. Panjang kaki depan bagian atas meliputi tulang tuberositas humerus diukur dari ekstremitas anterior sternum sampai pada olecranon process

11. Panjang kaki depan bagian bawah meliputi : radius, ulna, pisiform, metacarpus, phalang dari dua jari kaki yang besar, phalang dari kaki eksternal; diukur dari olecranon process sampai ke ujung phalang dari dua jari kaki yang besar.

12. Panjang kaki belakang bagian atas meliputi tuberositas anterior tibia, fibula diukur dari cup lutut sampai dengan calcaneum.

13. Panjang kaki belakang bagian bawah meliputi tarsus, metatarsus, phalang dari dua jari kaki yang besar, phalang dari kaki eksternal diukur dari calcaneum sampai ujung phalang dari dua jari kaki yang besar 14. Lebar kepala diukur pada sebelah kanan dan kiri (tepi luar procesus supraorbitalis dextra et sinistra) di bawah mata. 
15. Lebar leher diukur dari kulit sisi lateral os vertebrae cervicalis, mulai dari bagian kiri ke kanan

16. Lebar dada diukur dengan cara menarik garis horizontal antara tepi luar sendi bahu kiri dan kanan (tuberositas latelaris dari humerus dextra et sinistra) tegak lurus bidang median tubuh

17. Lebar pinggul diukur dengan cara menarik garis horizantal pada tepi luar tuber coxae kiri dan kanan tegak lurus bidang median tubuh.

18. Lebar pantat adalah jarak terlebar dari pantat, diukur dengan cara menarik garis horizontal dari kulit lateral tuber ischiuim dextra ke tuber ischiuim sinistra

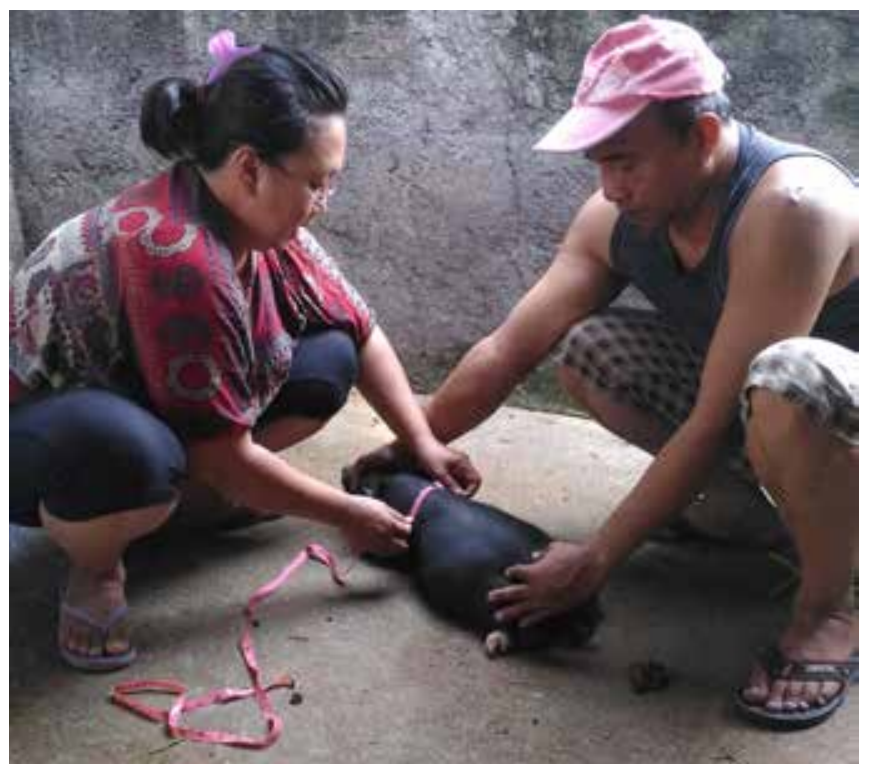

Gambar 6. Pengukuran dimensi tubuh dan testis babi bali

Pemilihan bibit pejantan yang baik dan memenuhi persyaratan, selain dari dimensi tubuhnya, terdapat hal yang penting diperhatikan yaitu: ukuran dan kondisi testis (Gambar 6). Hal ini dikarenakan performa reproduksi babi bali jantan yang meliputi ukuran testis dan kualitas semen, berkaitan erat dengan aktivitas dan kemampuan pejantan untuk mengawini sejumlah betina, memproduksi semen, dan tingginya fertilitas. Semakin bagus ukuran dan kondisi testis pejantan, akan berpengaruh secara nyata pada jumlah dan kualitas semen yang dihasilkan. Pada penelitian ini (Gambar 6), babi bali jantan lepas sapih mempunyai dimensi tubuh dan kondisi testis sebagi yang tercantum dalam Tabel 1.

Pengukuran dimensi tubuh ternak berdasarkan metode rotation promax kapa 90 (Sampurna, et al., 2015).

Babi bali secara genetik pertumbuhannya lebih lambat dibandingkan dengan babi ras impor. Diperlukan waktu 8-10 bulan untuk mencapai bobot badan 90-100 kg, sedangkan babi ras impor hanya 5-6 bulan. Tetapi kelebihannya, babi bali adalah
Tabel 1. Dimensi tubuh dan kondisi testis babi bali bibit pejantan di wilayah Nusa Penida*

\begin{tabular}{lc}
\hline \multicolumn{1}{c}{ Dimensi tubuh } & $\begin{array}{c}\text { Babi bali bibit pejantan } \\
\text { umur } 2 \text { bulan }\end{array}$ \\
\hline Panjang badan riil (cm) & 52 \\
Panjang kepala $(\mathrm{cm})$ & 13 \\
Panjang telinga $(\mathrm{cm})$ & 7 \\
Panjang ekor $(\mathrm{cm})$ & 18 \\
Panjang bulu punggung $(\mathrm{cm})$ & 2 \\
Lingkar dada $(\mathrm{cm})$ & 40 \\
Lingkar perut $(\mathrm{cm})$ & 52 \\
Lingkar pinggang $(\mathrm{cm})$ & 46 \\
Lebar testis kanan $(\mathrm{cm})$ & 7,50 \\
Lebar testis kiri $(\mathrm{cm})$ & 7,75 \\
Panjang testis kanan $(\mathrm{cm})$ & 7,25 \\
Panjang tetsis kiri $(\mathrm{cm})$ & 7,50 \\
Bobot badan $(\mathrm{kg})$ & 7,0 \\
\hline
\end{tabular}

*Ukuran rata-rata dari empat ekor pejantan

babi yang tahan menderita, lebih hemat terhadap air, masih mampu bertahan hidup walaupun di beri pakan seadanya (Budaarsa, 2012). Dewasa kelamin babi bali calon pejantan pada umur 7-8 bulan, namun peternak mengawinkan pertama kali pejantan ini pada umur 9-10 bulan dengan alasan pada umur 7-8 bulan tersebut, kondisi fisik calon pejantan belum siap untuk mengawini betina, atau dengan kata lain calon pejantan belum dewasa tubuh dengan sempurna.

Testis babi dewasa sangat besar tetapi relatif lebih lunak, dan terletak horizontal di dalam skrotom. Sebagai perbandingan, testis babi ras dewasa berbentuk lonjong dengan ukuran panjang 10-15 cm dan diameter 5-9 cm. Besarnya testis secara tidak langsung dapat diketahui dengan mengukur besar skrotom. Melalui pengukuran skrotom dapat diketahui kemampuan produksi sperma seekor pejantan dan dapat dimanfaatkan sebagai salah satu kriteria seleksi seekor pejantan. Besar dan ukuran skrotom berkolerasi positif dengan sperma yang dihasilkan oleh pejantan meliputi volume dan motilitas sperma serta kosentrasi spermatozoanya. Selain itu, ukuran skrotom juga berhubungan dengan umur dan berat tubuh dari berbagai bangsa babi. Perkembangan skrotom berjalan sesuai dengan pertumbuhan dan perkembangan tubuh secara keseluruhan. Semakin besar skrotom semakin banyak tubuli seminiferi dan makin banyak pula sperma yang dihasilkan. Masyarakat di wilayah Nusa Penida memberikan sebutan "raden" pada babi bali yang digunakan sebagai pejantan. Sistem perkawinan ternak babi bali di wilayah Nusa Penida, secara dominan masih menggunakan sistem kawin alami, yaitu betina yang sedang berahi akan dikawinkan dengan pejantan yang ada disekitar wilayah tersebut. Pemilik pejantan akan dibayar dengan satu ekor anak babi betina lepas sapih (umur 2-3 bulan) dari hasil perkawinan tersebut. 


\section{SIMPULAN}

Pemilihan bibit pejantan yang baik dan memenuhi persyaratan, dimensi tubuh dan testis, berkaitan erat dengan aktivitas dan produktivitas calon pejantan. Semakin tinggi dimensi tubuh dan ukuran testis calon pejantan babi bali, akan berpengaruh secara nyata pada reproduksi dari pejantan tersebut.

\section{UCAPAN TERIMAKASIH}

Ucapan terimakasih disampaikan kepada Universitas Udayana atas dana Hibah Unggulan Program Studi Universitas Udayana tahun 2016 yang telah diberikan, serta ucapan terimakasih kepada semua pihak yang telah membantu dalam proses penelitian ini.

\section{DAFTAR PUSTAKA}

Aberte, D. E., J.C. Forrest, D.F. Gerrard and E.W Mills. 2001. Principles of Meat Science. $4^{\text {th }}$ Edition. W.H. Freeman and Company. San Francisco, United States of America

Ardana, I.B dan D.K.H. Putra. 2008. Ternak Babi Manajemen Reproduksi, Produksi dan Penyakit. Udayana University Press. Denpasar.

Arifiantini, R.I dan L.Y. Tuty. 2012. Teknik Koleksi dan Evaluasi Semen pada Hewan. Bogor: IPB Press.

Ax R.L, M.Dally, B.A. Didion, R.W. Lenz, C.C. Love, D.D. Varner, B. Hafez, and M.E. Bellin. 2000. Semen Evaluation. In: Hafez ESE, Hafez B, editor. Reproduction in Farm Animals. $7^{\text {th }}$ Ed. USA: William \& Wilkins.

Boyles,S. 1991. The Bull's Scrotum and Testiceles. OSU Extension Beef Specialist. Available at http://beef.osu. edu/library/skrotom.html. (Accession date 1 March 2016).

Budaarsa, K. 2012. Babi Guling Bali. Dari Beternak, Kuliner hingga Sesaji. Penerbit Buku Arti. Denpasar. ISBN: 978-979-1145-69-5.

Budaarsa, K., A.W. Puger, I.M. Suasta. 2016. Ekplorasi komposisi pakan tradisional babi bali. Majalah Ilmiah Peternakan Vol 19 (1): 6-11. Fakultas Peternakan. Universitas Udayana.

Feradis. 2010. Reproduksi Ternak. Alfabeta. Bandung.

Gadea J. 2003. Semen extenders used in the arificial insemination of swine. Spanish Journal Of Agricultural Research 1 (2): 17-27.

Garner D. L and E. S. E. Hafez. 2000. Spermatozoa and Seminal Plasma. In: E. S. E. Hafez \& B. Hafez (Ed). Reproduction in Farm Animals. $7^{\text {th }}$ Ed. USA: William \& Wilkins.

Girisonta. 1981. Pedoman Lengkap Beternak Babi. Yogyakarta: Kanisius.

Hafez B, Hafez ESE. 200o. Reproductive Behavior. In: Hafez ESE, Hafez B, editor. Reproduction in Farm Animals. $7^{\text {th }}$ ED.USA: Wiliams \& Wilkins

Hafez E.S.E. 1993. Reproduction in Farm Animal. $5^{\text {th }}$ ed. Philadelphia: Lea \& Febiger.

Johnson LA, Weitze KF, Fiser P, Maxwell WMC. 2000. Storage of Boar Semen. J Anim Sci 62: 143-172

Kay, M.R., and Housseman. 1987. The Influence of Sex on Meat Production. In Meat Fd. D.J.A. Cook and R.A. Lawrrie Butterworth. London

Ningrum, A.P, Kustono, M. Hammam. 2008. Hubungan antara lingkar skrotom dengan produksi dan kualitas sperma pejantan Simmental di Balai Inseminasi Buatan Ungaran Jawa Tengah. Buletin Peternakan Vol. 32(2): 85-90.

Partodiharjo, S. 1987. Ilmu Reproduksi Hewan. Jakarta: Mutiara Sumber Widya.

Paulenz H, E. Kommisrud, and P.O. Hofmo. 2000. Effect of long-term storage at different temperaturs on the quality of liquid boar semen. Reprod. Dom. Anim 35: $83-85$

Robet, V. K. 2006. Semen Processing, Extending \& Storage for Artificial Insemination in Swine. Dep of Animal Science University of Illinois.

Salisbury,G.W dan N.L. Vandermak. (1985). Fisiologi Reproduksi dan Inseminasi Buatan pada Sapi. Terjemahan R. Djanuar. Yogyakarta: Gajah Mada University Press.

Sampurna I.P, T. S. Nindia, I. K. Suatha. 2015. Simulasi biplot menentukan laju pertumbuhan dimensi tubuh babi bali. Prosiding. Seminar Nasional Ternak Babi dan Kongres I AIBI. Fakultas Peternakan Universitas Udayana Denpasar. ISBN: 978-602-294-106-4. Pp: 131-146

Sihombing DTH. 2006. Ilmu Ternak Babi. Yogyakarta: Gadjah Mada University Press

Sumardani, N.L.G. 2007. Viabilitas dan Fertilitas Spermatozoa dalam Modifikasi Pengencer BTS dan Zorlesco dengan Penyimpanan Berbeda dalam Rangkaian Inseminasi Buatan pada Babi. Tesis. Bogor: IPB.

Steel, R.G.D. dan J.H. Torrie. 1980. Principle and Procedures of Statistics. McGraw-Hill Inc. New York. Diterjemahkan oleh: B. Sumantrini. 1993. Prinsip dan Prosedur Statistika. Jakarta: PT Gramedia Pustaka Utama.

Sudiastra, I. W. dan K. Budaarsa. 2015. Studi ragam eksterior dan karakteristik reproduksi babi bali. Majalah Ilmiah Peternakan Vol. 18 (3): 100-105.

Swatland HJ. 1984. Structure and Development of Meat Animals. Prentice-Hall Inc., Englewood Cliff, New Jersey

Toelihere, M.R. 1985. Fisiologi Reproduksi Pada Ternak. Bandung: Angkasa. 